\title{
11
}

\section{NATURE PREPARES THE SITES, BUT IT IS MAN WHO CREATES THE ORGANISM ${ }^{1}$}

\section{Bologna through Its Geography, Its History, and Its Planning Tools}

Valentina Orioli

\section{History and Geography Shape the Urban Structure}

In its origins Bologna summarizes the reasons for the spontaneous birth of an urban settlement and those for the voluntary creation of a city (Lavedan 1959, 18). In fact, if the city's site was inhabited since ancient times due to its characteristics particularly favorable to settlement, the present-day Bologna corresponds to a colony founded by the Romans.

Pre-Roman Bologna, whose birth dates to the 9th century BC, settled in a fertile plain, crossed by many rivers and yet sufficiently safe and protected to the south from the hilly slopes that form the Apennines. After the conquest of the Gauls, who had taken control of the territory from the Etruscans, in 189 BC the Romans established a colony called Bononia in the same area. Two years later, the consul Marcus Aemilius Lepidus completed the construction of the Via Aemilia, improving an existing foothills track. Via Aemilia connected the colonies from Ariminum (Rimini) to Placentia (Piacenza) and up to Mediolanum (Milan) and gave its name to the whole region (Dall'Aglio and Di Cocco 2006). It was part of a network of major roads that provided a safe way of traveling over the vast territory conquered by the Romans and ensured a connection with Rome, through the Po Valley and along the Adriatic coast, via the Via Flaminia. This network of consular routes was also the backbone of the limitatio system: a huge reclamation work, improving the distribution of water and creating at the same time a system of subdivision of rural areas into smaller plots, which were then allocated to the men who had served in the army.

Observing the imposing testimonies of ancient Rome during his Grand Tour of Italy, Johann Wolfgang von Goethe noted that the construction techniques of the Romans were of such great dimensions and power that they gave the impression of a landscape created by a "second nature, operating for civilian purposes" (Goethe 2017). As pointed out by Emilio Sereni (1993), this idea could certainly be extended to the network of Roman roads and to the pattern of the limitatio that is still clearly visible in many parts of Italian territory.

In the creation of the infrastructure network and in the choice of the location of the colonies, the Romans emphasized the strengths of the geography, highlighting some preexisting settlements and determining territorial patterns even after the end of the empire. 
Throughout the region Emilia-Romagna, this superimposed "second nature" is so strong that it has determined, as a first layer in the territorial palimpsest (Corboz 1983), the evolution of the infrastructure system and the urbanization dynamics, including contemporary urban sprawl in the whole plain (Brighi 2010; Gabellini et al. 2012).

Even if the monumental vestiges of ancient Bononia are not still visible in the contemporary city, the imprint of Roman colony has determined the organization of the oldest part of the historic center, acting like a sinopia (Ricci 1980) for the successive Medieval development.

Bologna is located between two rivers that flow very close to the city center to the east (river Savena) and west (river Reno). The presence of water, the location near the hillside in a safe and prosperous part of the plain, and the position along the Via Aemilia, which was the most stable track of the regional road network, allowed the city to survive after the collapse of Roman Empire, when the benefits of a good geographical location were the essential factor for the permanence of the urban settlements.

During the Middle Ages, Bologna established itself as a flourishing city thanks to agricultural production and to the creation of the Studium (in 1088), the oldest university of the Western world, and also due to the development of the manufacturing industry. These functions were boosted by the presence of the Via Aemilia, which not only determined the role of the city as a crossroads between the center and the north of Italy but also by the positive influence of a wide network of canals and waterways, literally built, starting from the locks on the two rivers (Pezzoli and Ugolini 2014; Tozzi Fontana 2001).

In the present-day Bologna, the presence of a network of natural and artificial canals is hardly noticeable, especially in the historic center, where they have mostly been completely covered. However, the smooth running of the urban water network is a decisive factor for the environmental equilibrium of the city, and the hydraulic artifacts built along the waterways are a significant part of the historical urban landscape that has long awaited a specific recovery and valorization plan (Cervellati et al. 1980).

The historic fountains are a tangible sign of the presence of water in the city. The Fontana Vecchia, located along Palazzo d'Accursio walls, and the Neptune fountain, are also the testimony of a vital connection with the nearby hills. Indeed, the fountains and the ancient aqueduct of the city are fed by a collection system that brings the water from the hills into the Cisterna di Valverde, a water tank designed in the 16th century by architect Tommaso Laureti, which gave architectural form to the hydraulic system conceived by the scholars of the Bolognese Studium (Tuttle 2001; Tuttle 2015; Gaiani 2017; Ferretti and Ceccarelli 2018).

These and other interventions for the construction of public spaces and monumental buildings took place in an urban fabric with overall defined morphology established during the Middle Ages and strongly influenced by the subsequent development of three different circles of walls, as well as by the course of roads and waterways.

The oldest structure, known as the "selenite walls," was built of stone blocks in the early Middle Ages. The walls surrounded only a part of the original Roman grid of Bononia. This retraction of the city conditioned its development also in the following centuries, establishing a fundamental difference between the parts of the historical urban fabric to the west and east of Piazza Maggiore.

The selenite enclosure, characterized by four crosses placed at the walls' angles, was enlarged after the conquest of the city by Liutprand, King of the Lombards, and the community of Lombards settled near the walls in the area of the church dedicated to the cult of 
Saint Stephen. The Lombards set the limits to this addition through a semicircular fortification, whose imprint is still clearly visible in the radial road pattern of the area.

The repopulation of the city from the 10th century and the city's growth as the seat of the Studium and as a center for agricultural and manufacturing production led to the construction of a second belt, called Torresotti or Cerchia del Mille, according to the time of construction. This second belt, which was 3.4-km long, had 18 gates, 4 of which still exist today. In 1183, the Treaty of Constance put an end to the struggles, in which Bologna had actively participated, against the domination of Frederick Barbarossa. After the treaty, the city grew quickly. At the end of the 13th century, Bologna had reached 60,000 inhabitants: it was the fifth largest city in Europe by population, after Cordoba, Paris, Venice, and Florence, and, with Milan, the largest textile manufacturing center in Italy. After the completion of the Torresotti circle, further space was immediately needed to allow for urban expansion. The new circle, called la Circla, built in the 14th century, was $7.6 \mathrm{~km}$ long and had 12 gates with drawbridges and was surrounded by a moat. Modified several times, this large circle of walls was demolished between 1902 and 1905 to allow for the development of the new urban plan approved in 1889. Only 10 of the gates and some sections of the walls are still visible today (Figure 11.1).

The succession of city walls allows to identify different parts of the city with different morphological characteristics. The selenite belt and the Lombards extension originally corresponded to the oldest and densest part of the city, including many towers and tower houses, and with a clear predominance of private spaces over public spaces: a "patrician city," with entire urban blocks "close," due to the houses faced mostly on interior courtyards and often interconnected by aerial walkways above the streets.

The population growth that had led to the construction of the Torresotti circle also produced other house extensions, often using "porticoes," to gain space above the streets. Even though the creation of these arcades is therefore generally described as a "disrespect of building regulations," their presence in the city of Bologna, on the contrary, provided the basis for the first rules applied to urban public space. With the Municipal bylaw of 1288, in fact, it was established that all houses must be equipped with "porticoes," the height and width of which were fixed at 7 Bolognese feet (2.66 meters), so as to easily allow through a man on horseback wearing a hat. Subsequent regulations were introduced to modify the dimensions or indications on the construction materials to be used (from wood to stone), in order to make these spaces safer and more functional (Bocchi 2019). Since 1288 to this today, no new regulations have ever been introduced to modify these fundamental characteristics of such private spaces, which are necessarily open to public use. Today, Bologna has porticoes situated along a stretch of $42 \mathrm{~km}$ inside the historic center, and $62 \mathrm{~km}$ throughout

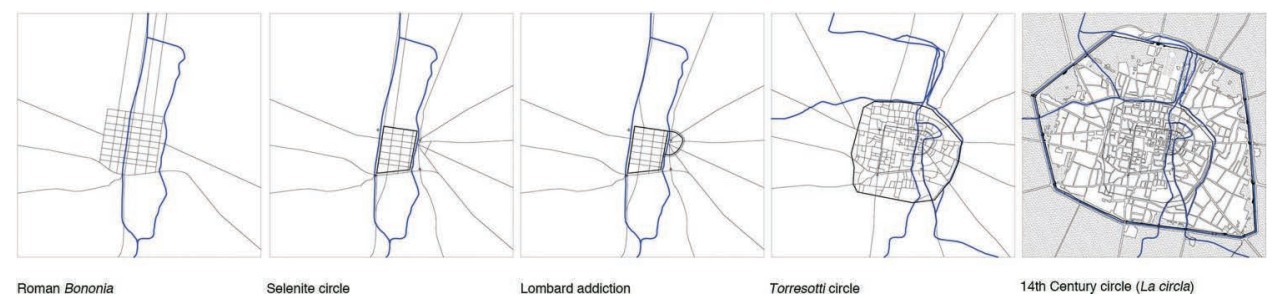

FIGURE 11.1 The city walls of Bologna, design by Martino Giani, 2019. 
the city, providing a network of protected but open pedestrian paths, expressing the social life of the city.

Until the end of the 19th century, the city of Bologna developed within the boundaries of its 14th-century walls. In fact, this enclosure outlined a very large area of more than 400 hectares, which until this time had not been completely filled with buildings. The city was densely built up at its inner center, corresponding to the Torresotti circle and along the main roads, but the density reduced progressively, to include many gardens, and even rural spaces, in the farther parts of the urban area, close to the ramparts.

The vital connection between the site and the city, and the main characters of urban structure outlined so far, are at the basis of the vision of the future proposed by contemporary planning tools.

The presence of water and natural elements in the city is reinterpreted today in a different, broader environmental perspective. It is no coincidence that it is the basis for the strategies and actions of the Climate Change Adaptation Plan approved in 2015 (Barbi et al. 2016). The quality and the management of open spaces have become increasingly important in public policies (Evangelisti 2012, 2017; Ginocchini, 2016), and along this line new planning paths have been developed, complementing the more traditional trajectories of urban planning, until the recent candidacy of the Porticoes to the UNESCO World Heritage List. ${ }^{2}$

Environmental goals and the preservation of historic urban landscape are at the base of the urban regeneration strategies of the new General Urban Plan adopted in 2020. ${ }^{3}$

\section{Planning over the City Walls}

The overcrossing of the city walls thresholds planned through the Piano regolatore e di ampliamento designed by Edoardo Tubertini in $1889^{4}$ (Scannavni et al. 1988) was not determined by the need to urbanize new areas to cope with population growth, but rather, as in many other Italian cities (Zucconi 2004), by the changed socioeconomic and political context and the progressive "opening" encouraged by the advent of new communication systems. In 1851, an international agreement started the construction of a railway line through central Italy, ${ }^{5}$ and later, the national network was developed and completed after the unification of Italy (1861). ${ }^{6}$ The arrival of the railway line and the construction of the train station in Bologna reinforced the historical role of the city as a "crossroads," creating the conditions for a new era of industrial development, thanks to the presence of the railway which began to replace the ancient roads and waterways as the essential transport and communication system, as had been the case since the Middle Ages (Figure 11.2).

The Urban Plan of 1889 concentrated the manufacturing and craft activities connected to the presence of the railway in a new urban area to the north of the railway station. The urban extension of Bologna, and particularly "La Bolognina," was designed according to the same principles that characterized the most important experiences in 19th-century urbanism in European cities, putting in place "a new concept of city, (...) that responded to the new liberal-rational order and whose values were those of the new machine age civilization" and "a new methodological attitude (...) based on the identification in the city construction process of an initial moment of planning, of the subsequent phases of urbanization and construction" (Solà-Morales 2010, 37-38).

Built according to the first modern Urban Plan and then subject to frequent modifications by virtue of a dynamism that is explained by its pivotal position between the historic 


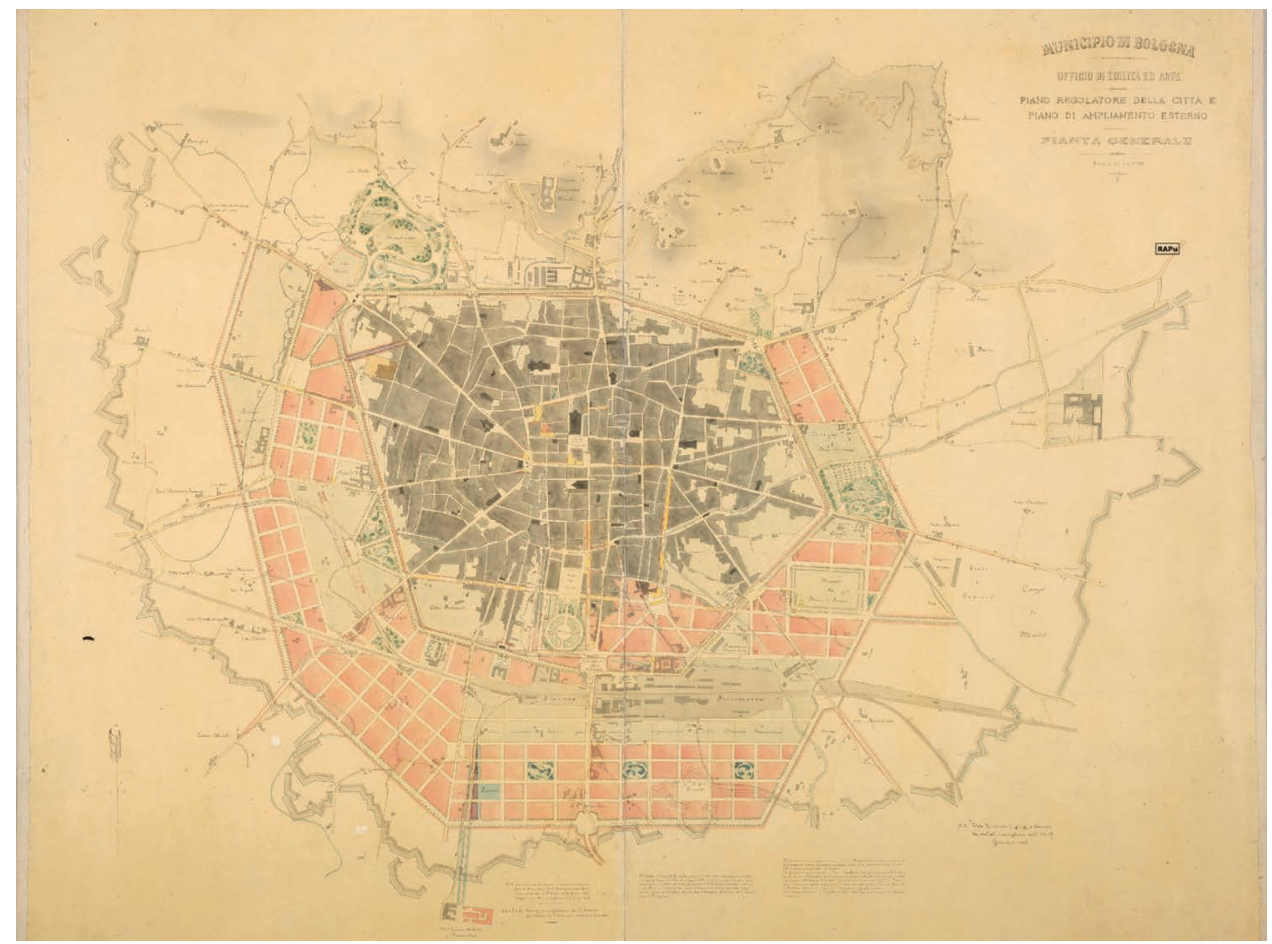

FIGURE 11.2 Municipio di Bologna, Piano regolatore della città e ampliamento esterno. Pianta generale, 1889.

urban center and a wider world connected to Bologna by rail, La Bolognina shows very well the subsequent transformations related to the evolution of planning. The part of $L a$ Bolognina actually built according to the plan of 1889 corresponds to the urban area located between Via Carracci, Fioravanti, Bolognese, and Matteotti. This area of the city, developed on a grid of regular blocks of $100 \times 140 \mathrm{~m}$, welcomed the first flows of immigration to Bologna and possesses even today a significant concentration of "historic" social housing. In the western part of the area, the city's new fruit and vegetable market began to develop in the 1930s, on a site with the advantage of its proximity to the railway network and in particular to Arcoveggio station. In the first postwar General Urban Plan, adopted in 1955, the area is classified as a "market expansion zone," and indeed the construction of the market, interrupted by the Second World War, was completed during the 1950s. The General Urban Plan accorded to the market the possibility to extend up to $250,000 \mathrm{~m}^{2}$ (Comune di Bologna 1964, 54; Figure 11.3).

The displacement of the market already foreseen in the General Urban Plan adopted in 1970 became a reality following the implementation of the successive 1985-1989 plan, ${ }^{7}$ with the effective relocation of this function in the new Centro agro alimentare bolognese, an area to the north of Pilastro neighborhood.

In the same years, a reflection was started on the redevelopment of the railway station and the railway junction of Bologna, following the bomb attack on August 2, 1980. In 1983, an international competition was launched, and in 1984 the jury led by Tomas Maldonado declared Zacchiroli's project the winner among five finalists. 


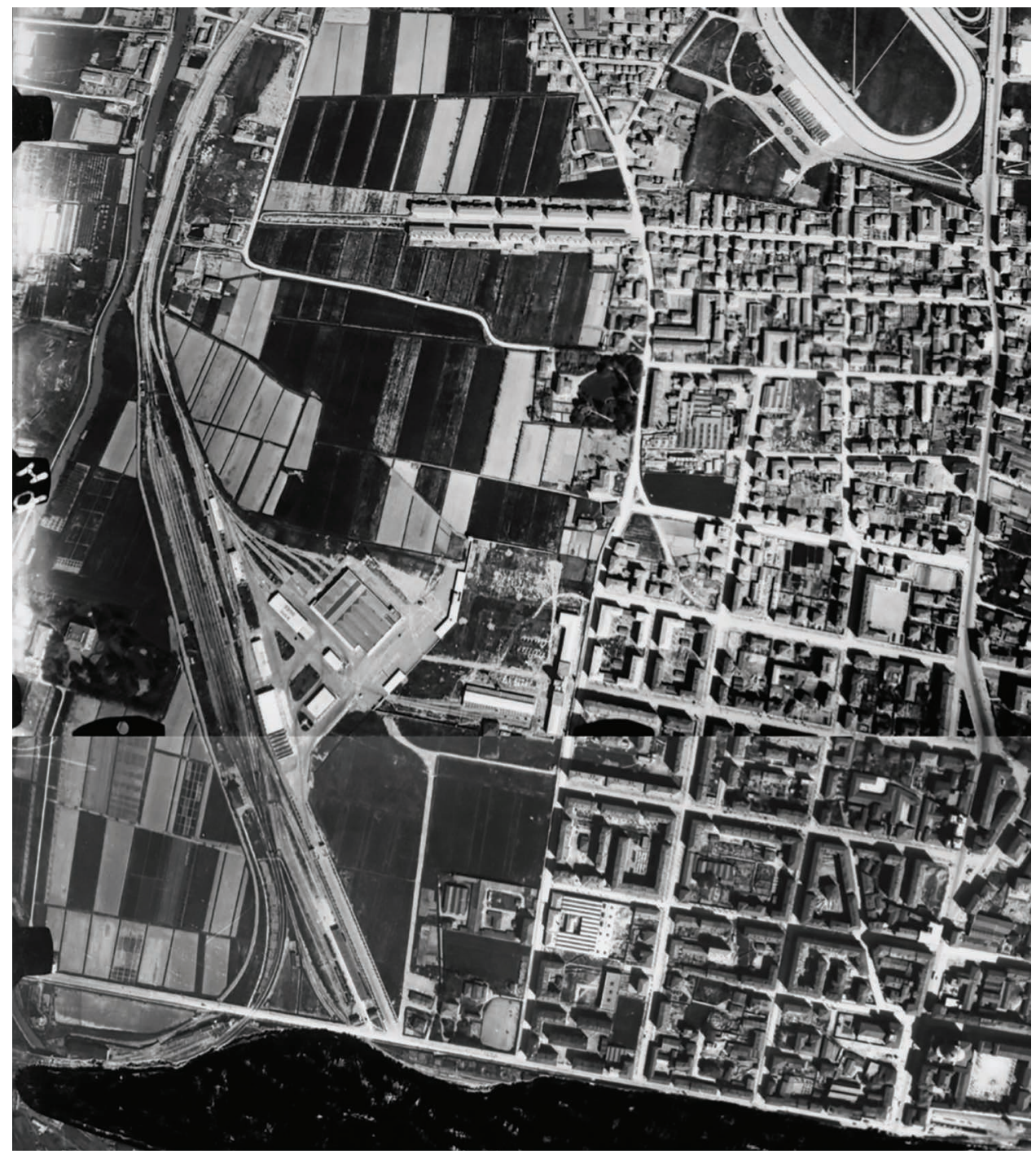

FIGURE 11.3 Aerial view of the market area in 1937, Comune di Bologna/Istituto geografico militare italiano.

The project was suddenly abandoned, and some years later Mayor Walter Vitali committed a masterplan of the whole railway area to Ricardo Bofill (1994). The masterplan developed by Bofill redefined the entire quarter around the railway station and included a new development of the former market area, following the lines of the orthogonal grid of 19th-century Bolognina (De Angelis 2016).

Two tall towers at the former market characterized the entire area as a new and modern gateway to Bologna. The controversy over the project, mainly due to the presence of the towers and the demolition of the ancient station, and the passage of the city government to the center-right in 1999, led to its abandonment despite the approval, in the same year, of a detailed masterplan drawn up by Tecnicoop. 
The new city government entrusted the formation of a new plan to Scagliarini studio (2004) and established the settlement of the new municipal offices in the area (Figure 11.4).

Despite the failure to realize them, these plans are proof of the importance accorded to the railway station and former market area for the future of the city of Bologna and constitute a set of "interrupted projects" that have left their mark on the definitive development undertaken after 2004 (Ginocchini and Tartari 2007).

The local elections in the same year, and the return of the center-left to the city government, provoked a further change in the former market plan, with a more participatory approach. Indeed, the adoption of Scagliarini's plan had immediately provoked strong opposition from

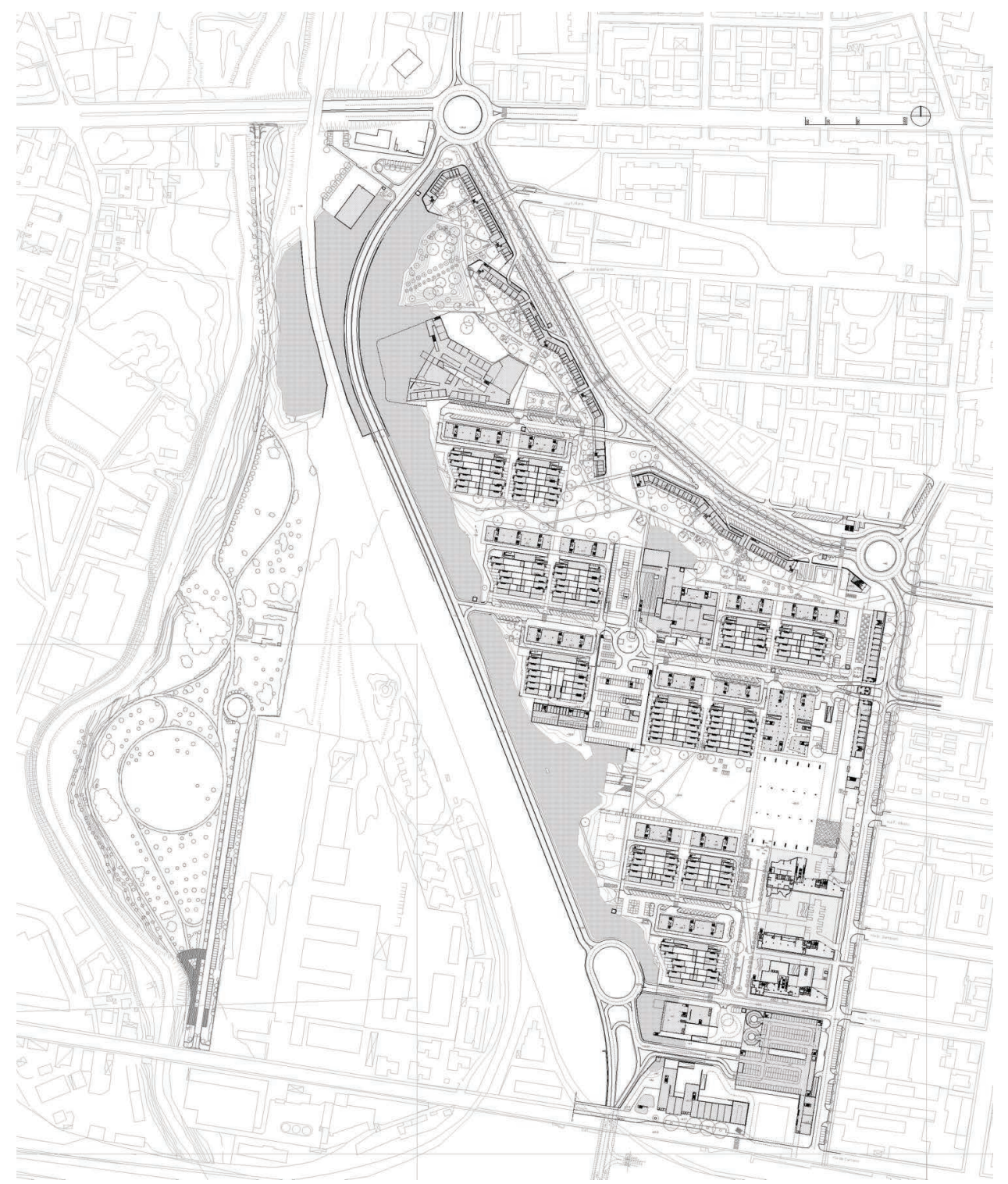

FIGURE 11.4 Plan for the former market area, 2004, Scagliarini Studio/TASCA studio architetti associati. 
the inhabitants of the area, and the new city council, headed by Mayor Sergio Cofferati, in 2005 set up a laboratory to discuss and modify the plan. The laboratory was the first test bench of the activities of the urban center (now Fondazione Innovazione Urbana, FIU) as an agency for information and discussion on issues related to urban development. The work carried out led to a redefinition of the project both from the point of view of different uses (with a more marked predominance of residential uses in preference to hotels and commercial and administrative functions) and a modification in the number of buildings, which was partly reduced (Figure 11.5).

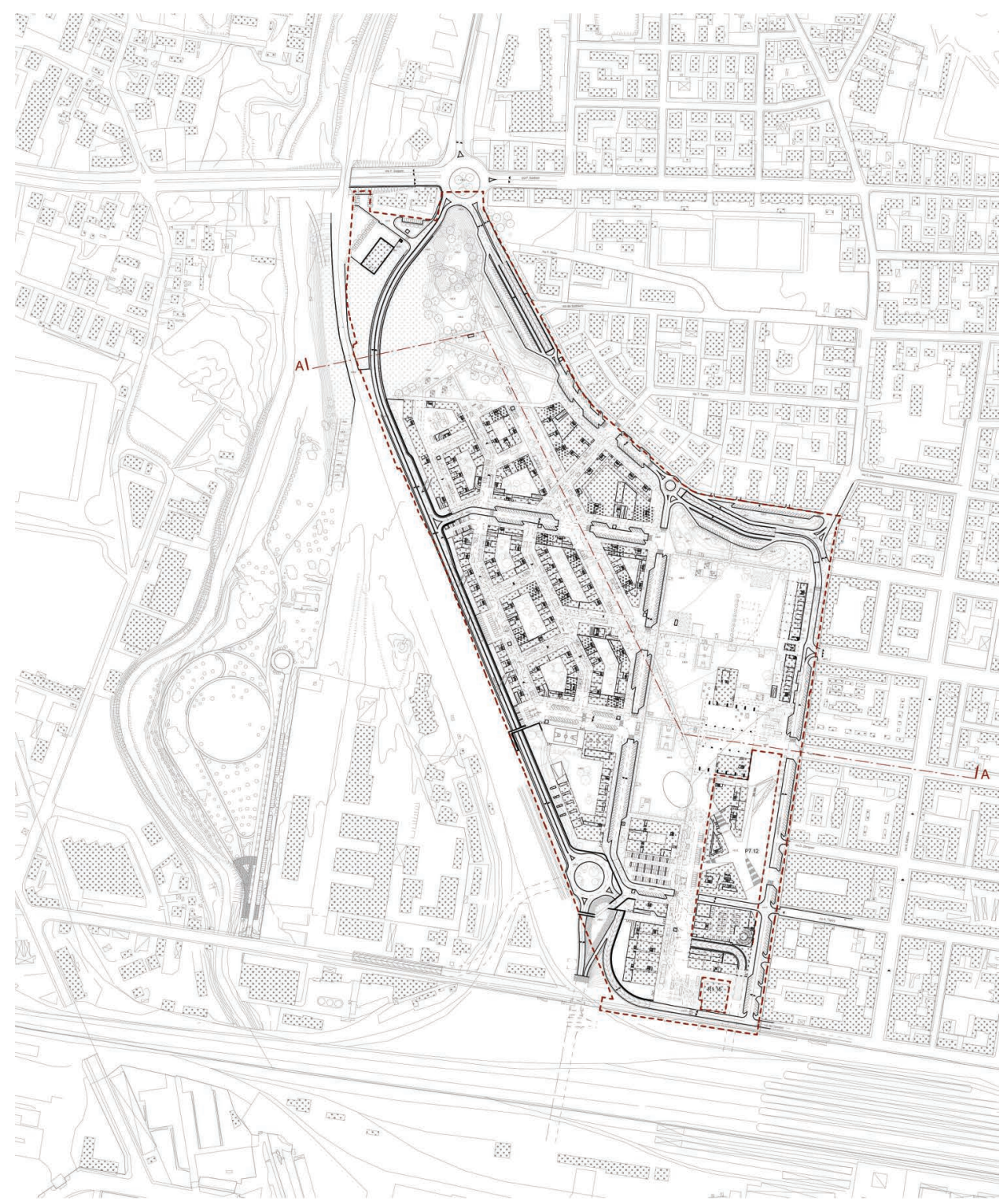

FIGURE 11.5 Second plan for the former market area, 2006, Scagliarini Studio/TASCA studio architetti associati. 
The project of the former market was carried out starting in the most difficult years of the economic crisis and almost immediately suffered a severe setback. Due to economic difficulties causing interruptions and serious delays for the private projects, the municipality, as owner of some of the land that was to be transformed, brought forward its share of funding for the public projects, in order to allow the overall design of the public spaces and facilities to be completed (Evangelisti 2016). The public intervention was intended to alleviate the discomfort of the inhabitants of the first residential buildings already constructed, who had gathered together in a committee to draw attention to their difficult situation of "pioneers" living in a large urban construction site. At the same time the municipality wanted to act as a motor, to help revive the project, and this now seems to be finally materializing.

For now, the old market renewal is nearing completion, with important public buildings such as the new town hall, new health services, a school, and a civic center under construction near the big ancient market canopy that will become a covered square, and private and public residential buildings built and under construction, in addition to a hostel and the headquarters of one of Bologna's major companies (Figure 11.6).

On the one hand, the historical identity of the area as a working-class district is maintained, to such an extent that today La Bolognina is the most multiethnic part of the city with a relevant public housing stock. On the other hand, the proximity to the city center and the ease of connection with the high-speed train station, whose construction started in 2004, recently completed with the link to the airport provided by the People Mover, reinforce the role of La Bolognina as a gateway to Bologna.

This characteristic blend was already recognized by the Municipal Structure Plan (PSC) of $2007,{ }^{8}$ which validated the importance of La Bolognina, including it in a "historic city" wider than the traditional "historic centre" (Evangelisti et al. 2008), and also it highlighted its vocation as a hybrid place, as a part of the "Railway City," rapidly and firmly connected to the rest of the world, thanks to its transport facilities.

This tension between maintaining a local identity and the sense of projection into a global world is today one of the characteristic features of Bologna. Being the place where the historic city began to transform and open up to modernity, La Bolognina is perhaps the place where these contradictions appear most, where the city "takes the shape of a metropolis (...) validating its transformation from a peasant town to a global town." So much so that, today, we can

definitely point out the existence of three different Bolognas, or rather of three different ways of referring to (...) the city: the metropolitan Greater Bologna; the idealised and romanticised intramural Bologna from the middle of the last century; and Little Bologna, that is to say La Bolognina, a district born at the time of the railways, and so also with the birth of a new way of functioning in the world in reference to spatial distances, and which today finds itself, more than any other part of the city, acting like an antenna, where another new way of functioning is appearing, to replace the old one. (...) Now, it is up to the first periphery of the city to play the role of a relay to connect to what is going on outside. And it is up to the Bolognese (...) to recognize and adopt in their own hearts the new composite form of the city, finally beginning to see it as it really is, in its totality, in its composite and dialectical nature, also from the point of view of its social relationships. 


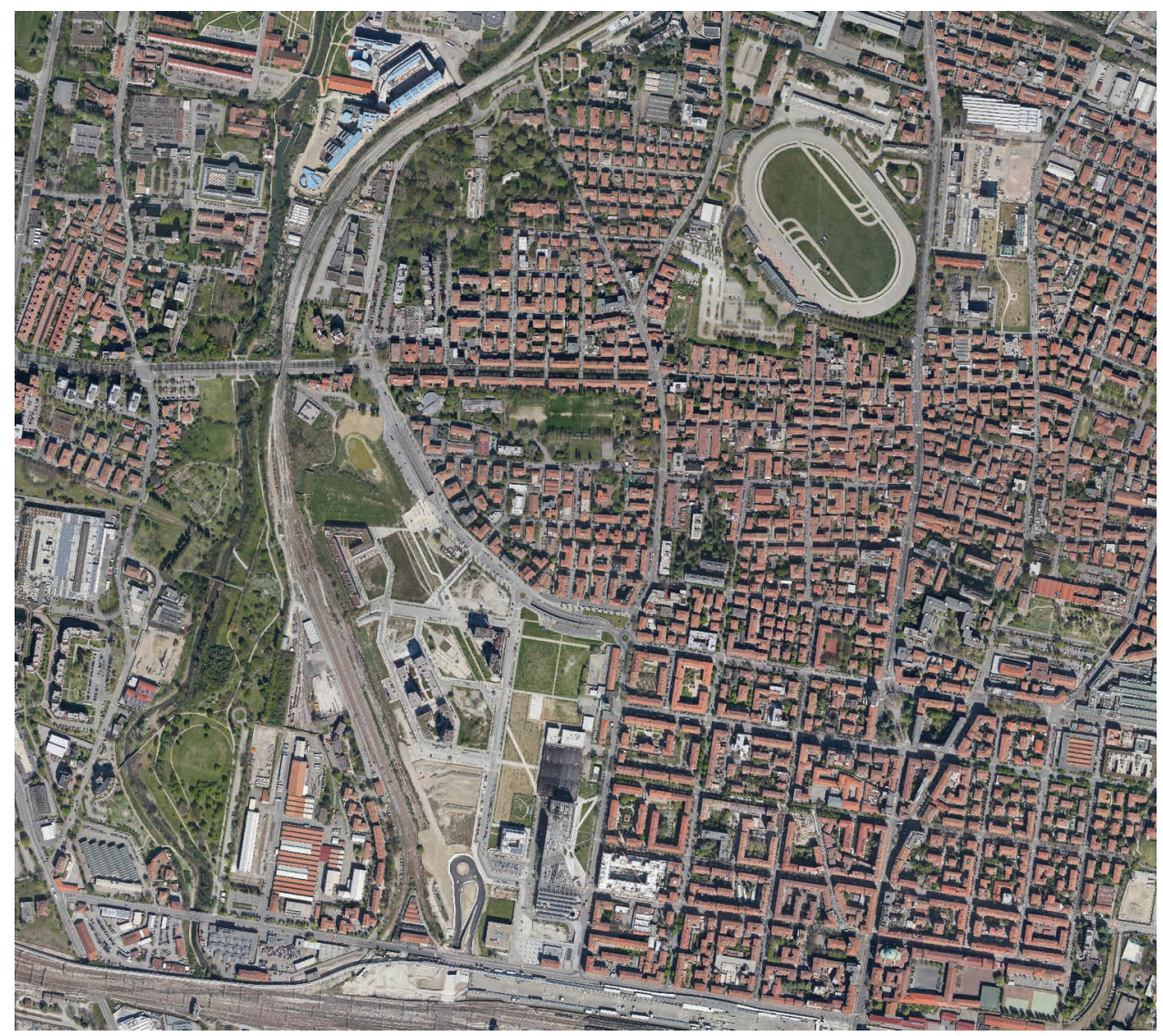

FIGURE 11.6 Aerial view of the former market area in 2020, Comune di Bologna.

\section{Notes}

1 "La nature prépare les sites; mais c'est l'homme qui crée l'organisme" is a quotation of Paul Vidal de la Blache's Principes de Géographie humaine (1922) reported by Pierre Lavedan in Géographie des Villes $(1959,17)$.

2 On the development and characteristics of the porticoes in Bologna, see the official site "Portici di Bologna" - Italian candidates for the UNESCO World Heritage List for 2021. http://www. comune.bologna.it/portici/

3 The new General Urban Plan (PUG) of Bologna is available at http://dru.iperbole.bologna. it/pianificazione?filter=Piano\%20Urbanistico\%20Generale $\% 20$ (PUG)

4 The Piano edilizio regolatore e di ampliamento della città di Bologna of 1889 is the first modern urban plan for the city. Laid out by the engineer Edoardo Tubertini, it is available for consultation at https://www.rapu.it/ricerca/scheda_piano.php?id_piano=131

5 The Convenzione fra alcuni Stati italiani per la costruzione della Strada Ferrata dell'Italia Centrale of 1851, signed by the PapalState, the Austro-Hungarian Empire and the Grand Duchy of Modena, Parma and Tuscany, is available at https://it.wikisource.org/wiki/Convenzione_fra_alcuni_Stati_italiani_ per_la_costruzione_della_Strada_Ferrata_dell\%27Italia_Centrale

6 The line Piacenza-Bologna was inaugurated in 1859; the line Bologna-Ancona in 1861. The same year, the connection with Milan was opened, thanks to the construction of a bridge over the river Po. 
7 The General Urban Plan of 1985, developed by Giuseppe Campos Venuti, Fernando Clemente, and Paolo Portoghesi, was approved in 1989 and can be consulted here http://www.arcgis. $\mathrm{com} / \mathrm{apps} /$ View/index.html?appid $=\mathrm{aa} 80 \mathrm{c} 34279 \mathrm{a} 4430 \mathrm{e} 96 \mathrm{~b} 7172243996 \mathrm{~d} 5 \mathrm{c} \& \mathrm{extent}=11.0220,44$. $1983,11.6427,44.7744$

8 The Municipal Structure Plan (PSC) adopted in 2007 and approved in 2008 had Patrizia Gabellini as a general consultant and is available for reference at http://www.comune.bologna. it/psc/articoli/1797

\section{Bibliography}

Aymonino, C., Brusatin, M., Fabbri, G., et al., 1970, La città di Padova. Saggio di analisi urbana. Roma, Officina edizioni.

Barbi, V., Fini, G., and Gabellini, G., eds., 2016, Bologna città resiliente. Sostenibilità energetica e adattamento ai cambiamenti climatici. Bologna, Quaderni di Urban Center https://www.fondazionein novazioneurbana.it/images/quaderni/PAES_LR.pdf

Bocchi, F., ed., 2019, I portici di Bologna e l'edilizia minore medievale. Bologna, Grafis (1st ed. 1990).

Brighi, E., 2010. La via Emilia tra Rimini e Forlì. Ruolo e immagine della strada. PhD Thesis, Alma Mater Studiorum Università di Bologna, Dottorato di ricerca in Composizione architettonica, XXII Ciclo.

Cervellati, P. L., Dallerba, G., and Salomoni, C., eds., 1980, Il canale Navile. Bologna, Graficoop.

Comune di Bologna., 1964, Piano regolatore generale della città di Bologna. Relazione. Bologna, ITIAV http://www.comune.bologna.it/storiaamministrativa/media/files/piano_regolatore_generale_ della_citta_di_bologna_relazione.pdf

Corboz, A., 1983. Le territoire comme palimpseste. Diogène 121: 14-35.

Dall'Aglio, P., and Di Cocco, I., eds., 2006, La linea e la rete: formazione storica del sistema stradale in Emilia-Romagna. Milano, TCI.

De Angelis, C., 2016, Tra fantasia e utopia: i progetti interrotti per Bologna. In: Bologne possibili, ed., B. Bettazzi et al., 21-75. Bologna, Istituto Beni Culturali della Regione Emilia-Romagna.

Evangelisti, F., 2012, Di nuovo in centro. Una nuova pedonalità per Bologna. Urbanistica Informazioni 242: 51-53.

Evangelisti, F., 2016, Trasformazioni interrotte: come garantire l'abitabilità. Urbanistica 158: 68-77.

Evangelisti, F., 2017, Tutela e riqualificazione dello spazio pubblico nel centro storico di Bologna: esperienze recenti. Arredo e Città 2: 128-143.

Evangelisti, F., Orlandi, P., and Piccinini, M., eds., 2008, La città storica contemporanea. Ferrara, Edisai http://www.fondazioneinnovazioneurbana.it/images/stories/collanaeditoriale/02_CittAStorica. pdf

Farinelli, F., 2019, Un'altra forma di città. Il Corriere di Bologna 1: 5.

Ferretti, E., and Ceccarelli, F., eds., 2018, Il Nettuno architetto delle acque. Bologna. L'acqua per la città tra Medioevo e Rinascimento. Bologna, Bononia University Press.

Gabellini, P. et al., 2012, Immagini del cambiamento in Emilia-Romagna, Bologna, Compositori http:// www.planum.net/journals-books/immagini-del-cambiamento-in-emilia-romagna

Gaiani, M., ed., 2017, Nettuno. La fontana: studio, progetto, restauro. Bologna, Bononia University Press. Ginocchini, G., 2016, Il confronto con la città: dentro l'agenda politica. Urbanistica 158: 83-85.

Ginocchini, G., and Tartari, C., eds., 2007, Il Mercato: una storia di rigenerazione urbana a Bologna. Ferrara, Edisai https://www.fondazioneinnovazioneurbana.it/images/stories/collanaeditoriale/01_ Mercato.pdf

Goethe, J. W., 2007, Viaggio in Italia. Milano, Mondadori (or ed Italienische Reise, 1816-1817).

Lavedan, P., 1959, Géographie des villes. Nouvelle edition. Paris, Gallimard (1st ed. 1936).

Orioli, V., 2008, Cesenatico. Turismo e città balneare fra Otto e Novecento. Firenze, Alinea.

Orioli, V., 2017, Il quartiere di Case Finali e il piano PEEP di Cesena. In: Le forme dello spazio abitabile. Trasformazioni dell'housing sociale a Cesena, Forli, Bologna, Bologna, ed. V. Balducci and V. Orioli, 75-89. Bologna, Bononia University Press. 
Orioli, V., and Massari, M., 2020, The plan for the conservation of the historic center of Bologna: a double legacy. In: Bologna and Kanazawa. Protection and valorization of two historic cities, ed. N. Inoue and V. Orioli, 125-149. Bologna, Bononia University Press.

Pezzoli, S., and Ugolini, M. C., eds., 2014, Bologna città d'acque. Bologna, Compositori.

Ricci, G., 1980, Le città nella storia d'Italia. Bologna. Roma-Bari, Laterza.

Scannavini, R., Palmieri, R., and Marchesini, M., 1988, La nascita della città postunitaria 1889-1939. La formazione della periferia storica di Bologna. Bologna, Nuova Alfa.

Sereni, E., 1993, Storia del paesaggio agrario italiano. Roma-Bari, Laterza (1st ed. 1961).

Solà-Morales, M., 2010, Cerdà/Ensanche. Barcelona, UPC.

Tozzi Fontana, M., ed., 2001, Bologna e l'invenzione delle acque: saperi, arti e produzione fra '500 e ' 800. Bologna, Compositori.

Tuttle, R. J., 2001, Piazza Maggiore. Studi su Bologna nel Cinquecento. Venezia, Marsilio.

Tuttle, R. J., 2015, The Neptune fountain in Bologna. Bronze, Marble and Water in the Making of a Papal City, ed. N. Aksamija and F. Ceccarelli. London, Brepols.

Zucconi, G., 2004, La città dell'Ottocento. Roma-Bari, Laterza (1st ed. 2001). 